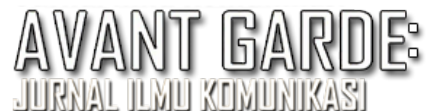

\title{
Faktor-Faktor Yang Mempengaruhi Keputusan Mahasiswa Memilih Program Studi Ilmu Komunikasi Untuk Menentukan Strategi Komunikasi Pemasaran Fikom Budi Luhur
}

\author{
Bintarto Wicaksono, Rini Lestari, Mulyati \\ e-mail: bintarto.wicaksono@budiluhur.ac.id \\ Universitas Budi Luhur, Jl. Ciledug Raya, Petukangan Utara, Jakarta Selatan, 12260
}

Submitted: 01 December 2019 Revised: 14 December 2019 Accepted: 19 December 2019

\begin{abstract}
Abstrak
Penelitian ini didasari oleh adanya pertanyaan mengenai faktor-faktor apa sajakah yang mempengaruhi mahasiswa dalam memilih program studi Ilmu Komunikasi di Universitas Budi Luhur, Jakarta yang selanjutnya akan dijadikan bentuk-bentuk strategi dalam promosi. Penelitian ini merupakan penelitian kuantitatif dengan menggunakan metode survei. Informasi digali dan disajikan dengan metode Analisi Faktor. Tahapan dalam penelitian ini diawali dengan studi literatur, menentukan variabel dan indikator. Data lapangan dikumpulkan melalui penyebaran kuesioner disajikan sesuai fakta yang ada, terorganisir dan sistematis. Hasil penelitian ini menunjukkan bahwa faktor paling dominan mahasiswa memutuskan untuk memilih prodi Ilmu Komunikasi adalah faktor kelompok reference yaitu saran dari guru, teman, dan orangtua. Selanjutnya dari hasil penelitian di turunkan dalam strategi-strategi promosi oleh tim Promosi dan Peneriamaan mahasiswa baru Universitas Budi Luhur Jakarta.
\end{abstract}

Kata Kunci: analisis faktor, strategi komunikasi, survei

\begin{abstract}
This research is based on the question of what factors influence students in choosing the Communication Studies program at Budi Luhur University, Jakarta, which will then be used as forms of strategy in promotion. This research is a quantitative study using survey methods. Information is extracted and presented using the Factor Analysis method. The stages in this research begin with the study of literature, determining variables and indicators. Field data collected through the distribution of questionnaires are presented in accordance with available facts, organized and systematic. The results of this study indicate that the most dominant factor of students deciding to choose the Communication Studies study program is the reference group factor, namely suggestions from teachers, friends, and parents. Furthermore, the results of the research were revealed in the promotion strategies by the Promotion Team of new students at Budi Luhur University Jakarta.
\end{abstract}

Keywords: factor analysis, communication strategic, survey

\section{PENDAHULUAN}

Memilih tempat kuliah dan jurusan yang akan diambil bukanlah hal yang mudah dan sederhana. Banyaknya jurusan atau program studi yang ditawarkan di perguruan tinggi terkadang membuat calon mahasiswa dan orangtua mencari tahu keunggulan dan prospek kerja lulusan dari program studi tersebut. Ilmu Komunikasi belakangan ini berkembang pesat sekali, minat calon mahasiswa kuliah di jurusan komunikasi terus bertambah. Jurusan Ilmu Komunikasi tumbuh subur di seluruh Indonesia.

Besarnya animo calon mahasiswa yang memilih jurusan ilmu komunikasi Universitas Budi Luhur tentunya dipengaruhi faktor-faktor tertentu. Terdapat banyak faktor yang mempengaruhi seseorang dalam mengambil keputusan berdasarkan kajian penelitian yang dilakukan oleh Risnawati 
dan Irwandi (2012:65) faktor-faktor tersebut adalah citra, minat, keputusan bersama, dan tersedianya lapangan kerja. Penelitian (2011) Muzamil dan Harsasi menemukan 4 faktor yaitu; reputasi, fleksibilitas, fasilitas, dan kelompok reference.

Berdasarkan latar belakang ini peneliti bermaksud melakukan survei terhadap mahasiswa baru angkatan 2018 Fakultas Ilmu Komunikasi Universitas Budi Luhur Jakarta. Tujuan survei tersebut adalah untuk mengidentifikasi faktorfaktor apa yang mempengaruhi mahasiswa dalam memilih Program Studi Ilmu Komunikasi.

\section{Tabel 1}

Jumlah mahasiswa program studi Ilmu Komunikasi tahun 2015-2017

Universitas Budi Luhur Jakarta

\begin{tabular}{|l|c|l|l|r|}
\hline Tahun angkatan & 2015 & 2016 & 2017 & 2018 \\
\hline Jumlah Mahasiswa & 910 & 809 & 627 & 615 \\
\hline
\end{tabular}

Sumber: DTI Universitas Budi Luhur

Penelitian diawali dengan melakukan studi literatur dengan tema serupa yang peneliti lakukan dengan cara membaca sebanyak-banyaknya referensi dari jurnal-jurnal yang ada. Beberapa penelitian yang menjadi bahan kajian literatur tersebut antara lain adalah: penelitian berjudul "Faktor-faktor yang Mempengaruhi Mahasiswa Memilih Program Studi Akuntansi Universitas Terbuka" karya Moh. Muzamil dan Meirani Harsasi yang dipublikasikan oleh Universitas terbuka pada tahun 2011. Penelitian tersebut dilakukan untuk mengetahui factor-faktor yang menjadi alasan kuat mahasiswa memilih program studi akuntansi Universitas Terbuka. Hasil penelitian menunjukkan bahwa faktor penentu pemilihan program studi Akuntansi UT meliputi reputasi, fleksibilitas, fasilitas, dan kelompok acuan. Ada juga penelitian lain yang berjudul "Analisis Faktor atas Pengambilan Keputusan Mahasiswa Untuk Memilih Jurusan Akuntansi di STIE Perbanas Surabaya" karya Erlita Risnawati dan Soni Agus Riswandi (2012). Hasil penelitian ini adalah dari hasil analisis faktor menunjukkan bahwa semua variabel yang berjumlah enam belas berpengaruh terhadap pemilihan jurusan akuntansi di STIE Perbanas. Faktor tersebut terdiri dari empat faktor utama yaitu (citra, minat, keputusan bersama, tersedianya lapangan kerja) dan satu faktor temuan baru (layanan dan fasilitas kampus yang sangat menunjang).

Terakhir penelitian berjudul "Analisis Faktor-faktor yang Mempengaruhi Keputusan Mahasiswa Dalam Memilih Program Studi oleh Marhadi Saputro (2017) Hasil penelitian adalah: (1) faktor-faktor yang mempengaruhi keputusan mahasiswa dalam memilih Program Studi Pendidikan Matematika adalah faktor keluarga, teman sejawat, kepribadian calon mahasiswa, sekolah asal, citra kampus, dan prospek lapangan kerja; (2) faktor-faktor tersebut secara bersamaan memberikan pengaruh terhadap keputusan mahasiswa dalam memilih program studi; dan (3) citra kampus dan prospek lapangan kerja merupakan faktor yang paling berpengaruh 
terhadap keputusan mahasiswa dalam memilih program studi.

\section{Perilaku Konsumen}

Menurut Kottler (2009 : 166) perilaku konsumen adalah studi tentang bagaimana individu, kelompok, dan organisasi memilih, membeli, menggunakan, dan bagaimana barang, jasa, ide, atau pengalaman untuk memuaskan kebutuhan dan keinginan mereka. Swastha dan Handoko (2000 : 10) mendefinisikan perilaku konsumen sebagai kegiatan - kegiatan individu yang secara langsung terlibat dalam mendapatkan dan mempergunakan barang - barang dan jasa - jasa, termasuk didalamnya proses pengambilan keputusan pada persiapan dan penentuan kegiatan - kegiatan tersebut.

Menurut Kotler (1997 : 153) faktor utama yang mempengaruhi perilaku pembelian konsumen yaitu faktor budaya, faktor sosial, faktor pribadi dan faktor psikologis. Menurut Sunarto (2004 : 97) pembelian konsumen secara kuat dipengaruhi oleh karakteristik budaya, sosial, pribadi dan psikologis.

a. Faktor budaya

Faktor budaya dipengaruhi oleh budaya, sub budaya dan kelas sosial. Budaya adalah penentu keingian dan perilaku yang paling mendasar. Budaya juga merupakan kumpulan nilai - nilai dasar, persepsi, keinginan dan tingkah laku yang dipelajari oleh seorang anggota masyarakat dari keluaraga dan lembaga penting lainnya. Menurut Schifman \& Kanuk (2008 : 358) budaya adalah keseluruhan kepercayaan, nilai - nilai, dan kebiasaan yang mempelajari yang membantu mengarahkan perilaku konsumen para anggota masyarakat tertentu. Budaya memperlengkapi orang dengan rasa identitas dan pengertian akan perilaku yang dapat diterima di dalam masyarakat. Budaya merupakan karakter yang penting dari suatu sosial yang membedakan dari kelompok kultur lainnya. Apa yang dimakan seseorang, bagaiman mereka berpakaian, apa yang mereka pikirkan dan rasakan, bahasa apa yang mereka bicarakan adalah dimensi dari kultur (Setiadi, 2008 :334). Menurut Sumarwan ( 2002 : 195) budaya adalah segala nilai, pemikiran, simbol yang mempengaruhi perilaku, sikap, keperrcayaan, dan kebiasaan seseorang dan masyarakat. Setiap budaya terdiri dari subbudaya yang lebih kecil yang memberikan lebih banyak ciri-ciri dan sosialisasi khusus bagi anggota - anggotanya. Pada dasarnya masyarakat memiliki strata sosial. Stratifikasi lebih sering ditemukan dalam bentuk kelas sosial. Sedangkan menurut Sumarwan (2002 : 218) kelas sosial merupakan bentuk lain dari pengelompokan masyarakat ke dalam kelas atau kelompok yang berbeda. Kelas sosial akan mempengaruhi jenis produk, jenis jasa, dan merek yang dikonsumsi oleh konsumen. Kelompok status mencerminkan suatu harapan komunitas akan gaya hidup di kalangan masing-masing kelas dan juga estimasi sosial yang positif atau negatif mengenai kehormatan 
yang diberikan kepada masing masing kelas (Setiadi, 2008 : 299).

b. Faktor sosial

Dalam faktor sosial, kelompok referensi, keluarga, peran sosial dan status mempengaruhi perilaku pembelian. Kelompok referensi (reference group) adalah semua kelompok yang mempunyai pengaruh langsung (tatap muka) atau tidak langsung terhadap sikap atau perilaku orang tersebut. Menurut Assel (dalam Sutisna, 2002 :176) kelompok rujukan atau kelompok referensi adalah kelompok yang berfungsi sebagai poin rujukan bagi individu dalam membentuk kepercayaan, sikap dan perilakunya. Adapun jenis - jenis kelompok referensi menurut Engel, et al (1994: 167) :

1. Kelompok Primer dan Kelompok Sekunder

Kelompok primer merupakan kelompok dengan interaksi yang tidak terbatas, sesama anggotanya sudah saling mengenal dan memperlihatkan kesamaan yang mencolok dalam 4 kepercayaan dan perilaku. Sedangkan kelompok sekunder adalah kelompok yang interaksinya bersifat lebih sporadis, kurang komperhensif, dan kurang berpengaruh dalam membentuk gagasan dan perilaku.

2. Kelompok Aspirasi dan Kelompok Disosiatif

Kelompok aspirasi merupakan kelompok yang didalamnya terdapat keinginan untuk mempergunakan norma, nilai serta perilaku orang lain. Sedangkan kelompok disosiatif adalah kelompok yang nilai nilainya atau normanya berusaha dihindari oleh orang lain.

3. Kelompok Formal dan Kelompok Informal

Kelompok formal merupakan kelompok yang memiliki peraturan - peraturan yang tegas, organisasi dan strukturnya dimodifikasi secara tertulis dan hubungan antara anggotanya didasarkan pada aturan yang telah ditetapkan. Sedangkan kelompok informal merupakan kelompok dengan lebih sedikit struktur dan mungkin didasarkan pada persahabatan atau persamaan persamaan yang dimiliki anggotanya.

Keluarga adalah kelompok yang terdiri dari dua atau lebih orang yang berhubungan darah, perkawinan atau adopsi dan tinggal bersama (Engel, 1994 : 194). Sedangkan menurut Mangkunegara (2002 : 44) keluarga adalah suatu unit masyarakat yang terkecil yang perilakunya sangat mempengaruhi dan menentukan dalam pengambilan keputusan. Macam - macam bentuk keluaraga menurut Swastha dan Handoko (2000 : 70) adalah sebagai berikut :

1. Keluarga inti (nuclear family), menunjukan 
lingkup keluarga yang meliputi ayah, ibu dan anak yang hidup secara bersama.

2. Keluarga besar (extended family), yaitu keluarga inti ditambah dengan orang orang yang memi;liki ikatan saudara dengan keluarga tersebut, seperti kakek, nenek, paman dan menantu. Dalam menganalisis perilaku konsumen, faktor keluarga dapat berperan sebagai berikut (Mangkunegara, 2002 : 44)

1. Siapa yang mengambil inisiatif

2. Siapa yang memberi pengaruh

3. Siapa yang mengambil keputusan

4. Siapa yang melakukan pembelian

Pemakai, Kelompok sering menjadi sumber informasi penting dalam mendefinisikan norma perilaku.

Menurut Simamora

(2001: 9) tiap peran membawa status yang mencerminkan penghargaan umum oleh masyarakat. Peran (role) terdiri dari kegiatan yang diharapkan dapat dilakukan seseorang. Setiap peran menyandang status. Orang - orang memilih produk yang mengkomunikasikan peran dan status mereka.

c. Faktor pribadi

Faktor pribadi meliputi usia dan tahap dalam siklus hidup pembeli, pekerjaan dan keadaan ekonomi, kepribadian dan konsep diri, serta gaya hidup dan nilai. Seseorang mengubah barang dan jasa yang mereka beli selama hidup mereka. Selera terhadap makanan, pakaian, dan rekreasi sering kali berhubungan dengan usia. Pekerjaan seseorang akan mengarahkan pada kebutuhan dan keinginan seseorang dalam mengkonsumsi barang amaupun jasa yang diinginkan. Pekerjaan juga mempengaruhi pola konsumsi. Para pemasar berusaha untuk mengidentifikasi kelompok pekerjaan yang memiliki minat lebih diatas rata- rata produk dan jasa yang mereka hasilkan. Pilihan produk sangat dipengaruhi oleh keadaan ekonomi yaitu pengahasilan yang dapat dibelanjakan, tabungan dan aset, kekuatan pinjaman, dan sikap terhadap pengeluaran dan tabungan. Menurut Simamora (2001 : 10) keadaan ekonomi sangat mempengaruhi pilihan produk. Pemasar yang produknya peka terhadap pendapatan dapat dengan seksama memperhatikan kecenderungan dalam pendapatan pribadi, tabungan, dan tingkat bunga. Jadi jika indikato indikator ekonomi tersebut menunjukan 5 adanya resesi, pemasar dapat mencari jalan untuk menetapkan posisi produknya.

Menurut Stanton (1996 : 159) kepribadian adalah pola ciri ciri seseorang yang menjadi determinan (faktor penentu) dalam perilaku responnya. Kepribadian adalah respon yang konsisten terhadap stimulus lingkungan (Engel, 1994 : 367).

Menurut Sumarwan (2002 : 56) gaya hidup menggambarkan pola dan perilaku seseorang, yaitu bagaimana ia hidup, menggunakan uangnya dan memanfaatkan waktu yang dimilikinya. Gaya hidup berbeda dengan kepribadian, walaupun berbeda gaya hidup dan kepribadian saling berhubungan. Keputusan konsumen juga dipengaruhi oleh nilai inti (core 
values), sistem kepercayaan yang mendasari sikap dan perilaku. Nilai inti lebih dalam daripada perilaku atau sikap dan menentukan pilihan dan keinginan seseorang pada tingkat dasar dalam jangka panjang.

d. Faktor psikologis pilihan pembelian seseorang dipengaruhi oleh empat faktor psikologis utama, yaitu motivasi, persepsi, pembelajaran, serta keyakinan dan pendirian. Motivasi menurut American Encyclopedia adalah kecenderungan (suatu sifat yang merupakan pokok pertentangan) dalam diri seseorang yang membangkitkan topangan dan tindakan. Motivasi meliputi faktor kebutuhan biologis dan emosional yang hanya dapat diduga dari pengamatan tingkah laku manusia (Setiadi, 2008 : 94). Motivasi konsumen adalah keadaan di dalam pribadi seseorang yang mendorong keinginan individu untuk melakukan kegiatan - kegiatan guna mencapai suatu tujuan. Menurut Setiadi (2008 : 160) persepsi adalah proses bagaimana stimuli - stimuli diseleksi, diorganisasikan, dan diinterpretasikan. Persepsi tidak hanya bergantung pada rangsangan fisik tetapi juga pada rangsangan yang berhubungan dengan lingkungan sekitar dan keadaan individu yang bersangkutan. Persepsi yang dibentuk oleh seseorang dipengaruhi oleh pikiran dan lingkungan sekitarnya. Menurut Setiadi (2008 : 187) pembelajaran dapat dipandang sebagai proses dimana pengalaman menyebabkan perubahan dalam pengetahuan, sikap atau prilaku.

\section{Proses Pengambilan Keputusan}

Pengertian keputusan adalah seleksi terhadap dua pilihan alternatif atau lebih (Schiffman \& Kanuk, 2008 :485).
Proses pengambilan keputusan yang rumit sering melibatkan beberapa keputusan suatu keputusan melibatkan pilihan diantara dua atau lebih alternatif tindakan. Keputusan selalu mensyaratkan pilihan diantara beberapa prilaku yang berbeda.

Terdapat lima peran yang terjadi dalam keputusan membeli :

1. Pemrakarsa (initiator)

2. Pemberi pengaruh (influencer)

3. Pengambil keputusan (decider)

4. Pembeli (buyer)

5. Pemakai (user) (Simamora, 2001 : 15)

Menurut Kotler dan Keller (2012 : 192), terdapat beberapa unsur yang menjadi perhatian dan pertimbangan konsumen dalam melakukan keputusan pembelian, yaitu :

1. Pilihan produk.

2. Pilihan merek.

3. Pilihan penyalur.

4. Waktu pembelian.

5. Jumlah pembelian.

6. Metode pembayaran.

Pengambilan keputusan sebagai proses penting yang memengaruhi perilaku konsumen dan harus dipahami oleh pemasar. Perilaku konsumen merupakan studi yang mengkaji bagaimana individu membuat keputusan untuk membelanjakan sumber daya yang tersedia dan dimiliki (waktu, uang, dan usaha) untuk mendapatkan barang atau jasa yang nantinya akan dikonsumsi (Suryani, 2018 : $6)$.

Terdapat dua faktor yang memengaruhi pengambilan keputusan pembelian yang selanjutnya akan menentukan respons konsumen :

1. Konsumen itu sendiri.

Ada dua unsur dari konsumen yang berpengaruh terhadap pengambilan keputusan yaitu pikiran konsumen yang meliputi kebutuhan atau 
motivasi, persepsi, sikap dan karakteristik konsumen yang meliputi demografis, gaya hidup, dan kepribadian konsumen.

2. Pengaruh lingkungan yang terdiri dari nilai budaya, kelas sosial, face to face group, dan situasi lain yang menentukan (Suryani, $2013: 6$ ).

\section{METODE PENELITIAN}

Jenis penelitian ini adalah deskriptif dengan pendekatan kuantitatif sedangkan metode penelitiannya adalah survei. Metode survey bertujuan untuk memperoleh informasi tentang sejumlah responden yang dianggap mewakili populasi tertentu (Kriyantono, 2007: 60).

Adapun variabel penelitian yang akan diteliti meliputi:

- Citra Program Studi Ilmu Komunikasi Universitas Budi Luhur

- Minat terhadap Prodi Ilmu Komunikasi UBL

- Alumni

- Lapangan Kerja

- Keputusan Kolektif

- Biaya Kuliah

- Sarana penunjang (laboratorium, perpustakaan, dll)

Populasi penelitian adalah

mahasiswa baru Fakultas Ilmu

Komunikasi tahun akademik 2018/2019 berdasarkan data per tanggal 3 September 2018 jumlah seluruh mahasiswa Fikom sebesar 359 orang.

Asumsi yang disampaikan oleh Gay dan Diehl (1992) mengatakan bahwa semakin besar sampel yang diambil maka semakin merepresentasikan bentuk dan karakter populasi serta lebih dapat untuk digeneralisir. Meskipun demikian, ukuran pasti sampel yang akan diambil sangat bergantung pada jenis penelitian yang sedang digarap.

Sampel penelitian ini ditentukan sebanyak $40 \%$ dari total populasi yaitu sebesar 144 mahasiswa. Teknik pengambilan sampel yang digunakan adalah purposive sampling yaitu teknik pengambilan sampel yang disesuaikan dengan karakteristik yang dibutuhkan dalam penelitian, dalam hal ini yaitu mahasiswa program studi ilmu komunikasi semester satu.

Metode pengumpulan data pada penelitian ini adalah berupa data primer. Data primer berasal dari hasil jawaban kuesioner yang peneliti sebarkan kepada seluruh populasi yaitu mahasiswa baru 2018 Fakultas Ilmu Komunikasi universitas Budi Luhur. Pengumpulan data dilakukan secara langsung di dalam kelas pada waktu jam kuliah. Jika mahasiswa tidak hadir waktu jam kuliah tersebut maka mereka gugur/tidak menjadi responden.

Analisis data dilakukan melalui uji validitas data dan uji realibilitas terlebih dahulu. Selanjutnya dilakukan analisis faktor-faktor apa saja yang menjadi penentu mahasiswa dalam memilih jurusan ilmu Komunikasi di Universitas Budi Luhur Jakarta.

Analisis faktor adalah prosedur untuk mengidentifikasi item/variabel berdasarkan kemiripannya. Kemiripan tersebut ditunjukkan dengan nilai korelasi yang tinggi. Item-item yang memiliki korelasi yang tinggi akan membentuk suatu kerumunan faktor. Dalam analisis faktor dikenal istilah konstrak empirik dan konstrak laten. Penelitian ini menggunakan item-item pertanyaan di dalam kuesioner dengan cara mengadopsi dari penelitianpenelitian sejenis sebelumnya dengan ditambahkan pertanyaan yang berhubungan dengan program studi Ilmu Komunikasi yang disesuaikan dengan landasan teoritis dan konseptual yang peneliti gunakan. 


\section{HASIL DAN PEMBAHASAN}

Berdasarkan data yang telah dikumpulkan melalui penyebaran kuesioner, maka selanjutnya data akan dianalisis dan di deskripsikan tahap demi tahap, yaitu karakteristik responden, proses penyebaran kuesioner, dan pengolahan data.

\section{Analisis Data Profil Responden}

Berdasarkan data per tanggal 3 September 2018 jumlah seluruh mahasiswa Fikom sebesar 359 orang. Sampel penelitian ditentukan sebesar $40 \%$ dari jumlah populasi yaitu sebanyak 144 mahasiswa. Dari 144 kuesioner ternyata tidak semuanya layak dijadikan sumber data, hanya 113 yang valid dan layak dijadikan sumber data.

\section{a. Profil responden berdasarkan jenis} kelamin

Responden yangmemilih kuliah di Program Studi Ilmu Komunikasi Universitas Budi Luhur Jakarta berdasarkan jenis kelamin yang dijadikan sampel penelitiansebanyak113 mahsiswa, jumlah mahasiswa berjenis kelamin lakilaki lebih banyakyang mengisi kuesioner daripada mahasiswa yang berjenis kelamin perempuan. Mahasiswa laki-laki sebesar $65 \%$ sedangkan mahasiswa perempuan sebesar 35\%. Dari hasil distribusi frekuensi terhadap jenis kelamin, bisa disimpulkan, yang lebih serius dalam mengisi kuesioner adalah laki-laki.

Hasil ini tidak dapat dijadikan indikator bahwa mahasiswa laki-laki yang lebih banyak memilih kuliah di Fikom daripada perempuan. Hasil ini hanya berdasarkan jumlah yang mengisi kuesioner dengan tepat.

\section{b. Pekerjaan Ayah dan Ibu}

Bekerjaan orang tua responden dipisahkan antara pekerjaan ayah dan pekerjaan ibu. Pekerjaan ayah terbanyak adalah pegawai swasta yaitu sebesar 34\% diikuti oleh wiraswastawan yaitu sebesar $30 \%$. Sedangkan pekerjaan ibu paling banyak dijawab yaitu lain-lain sebesar $66 \%$, lain-lain disini adalah sebagai ibu rumah tangga

\section{c. Responden Berdasarkan Daerah Asal}

Responden yang memilih Fakultas Ilmu Komunikasi sebagian besar berasal dari Jakarta dan Tangerang. Mahasiswa yang berasal dari Jakarta sebanyak 50 responden (44\%) dan yang berasal dari Tangerang sebanyak 34 responden (30\%), sisanya berasal dari berbagai daerah di Pulau Jawa, Bali, Sumatera, dan Sulawesi.

\section{Hasil Analisis Faktor \\ Tahap I}

Pada tahap pertama dilakukan analisis faktor, terdapat variabel yang nilai komunalitasnya $<0,5$, seperti pada tabel $\mathrm{di}$ bawah ini:

\section{Tabel 2}

Communalities

\begin{tabular}{|l|r|r|}
\hline & Initial & Extraction \\
\hline $\mathrm{X} 1$ & 1.000 & .802 \\
$\mathrm{X} 2$ & 1.000 & .759 \\
$\mathrm{X} 3$ & 1.000 & .587 \\
$\mathrm{X} 4$ & 1.000 & .603 \\
$\mathrm{X} 5$ & 1.000 & .565 \\
$\mathrm{X} 6$ & 1.000 & .307 \\
$\mathrm{X} 7$ & 1.000 & .758 \\
$\mathrm{X} 8$ & 1.000 & .732 \\
$\mathrm{X} 9$ & 1.000 & .683 \\
$\mathrm{X} 10$ & 1.000 & .549 \\
$\mathrm{X} 11$ & 1.000 & .688 \\
$\mathrm{X} 12$ & 1.000 & .749 \\
$\mathrm{X} 13$ & 1.000 & .815 \\
$\mathrm{X} 14$ & 1.000 & .791 \\
$\mathrm{X} 15$ & \multicolumn{3}{|c|}{1.000} & .670 \\
\hline
\end{tabular}


Sumber: hasil olah data dengan SPSS 23

Berdasarkan tabel komunalitas

diatas, terdapat 1 variabel yang mempunyai nilai komunalitas kurang dari 0,5 yaitu X.6. Maka selanjutnya akan dianalisis ulang tanpa X.6 tersebut.

\section{Tahap II}

\section{Uji Determinant of Correlation Matrix}

Asumsi Analisis Faktor yang pertama adalah: Uji Determinant of Correlation Matrix. Matrik korelasi dikatakan antar variabel saling terkait apabila determinan bernilai mendekati nilai 0. Hasil perhitungan menunjukkan nilai Determinant of Correlation Matrix sebesar 0.006. Nilai ini mendekati 0 , dengan demikian matrik korelasi antara variabel saling terkait.

\section{Kaiser Meyer Olkin Measure of Sampling}

Asumsi Analisis Faktor yang kedua adalah: Kaiser Meyer Olkin Measure of Sampling (KMO) adalah indek perbandingan jarak antara koefisien korelasi dengan koefisien korelasi parsialnya. Jika jumlah kuadrat koefisen korelasi parsial di antara seluruh pasangan variabel bernilai kecil jika dibandingkan dengan jumlah kuadrat koefisien korelasi, maka akan menghasilkan nilai KMO mendekati 1. Nilai KMO dianggap mencukupi jika lebih dari 0,5. Hasil KMO ditampilkan seperti di bawah ini: 
Tabel 3

KMO and Bartlett's Test

\begin{tabular}{|c|r|}
\hline $\begin{array}{l}\text { Kaiser-Meyer-Olkin Measure of Sampling Adequacy. } \\
\text { Bartlett's Test of Sphericity } \quad \text { Approx. Chi-Square }\end{array}$ & .793 \\
df & 944.962 \\
Sig. & .000 \\
\hline
\end{tabular}

Sumber: hasil olah data dengan SPSS 23

Hasil penelitian menunjukkan bahwa nilai Kaiser Meyer Olkin Measure of samplingsebesar 0,793. Dengan demikian persyaratan KMO memenuhi persyaratan karena memiliki nilai di atas 0,5 .

\section{Bartlett Test of Sphericity}

Asumsi Analisis Faktor yang pertama adalah: Bartlett Test of Sphericity. Hasil perhitungan dengan SPSS dihasilkan nilai Barlett Test of Spehricity sebesar 544.962 dengan signifikansi sebesar 0,000.

Dengan demikian Bartlett Test of Spehricity memenuhi persyaratan karena signifikansi di bawah 0,05 (5\%).

\section{Measures of Sampling Adequacy (MSA)}

Pengujian persyaratan MSA terhadap semua variabel, dijelaskan pada tabel di bawah ini:

Tabel 4 Measures of Sampling Adequacy (MSA)

\begin{tabular}{|c|c|}
\hline Variabel & MSA \\
\hline $\mathrm{X} 1$ & 0.676 \\
\hline $\mathrm{X} 2$ & 0.720 \\
\hline $\mathrm{X} 3$ & 0.838 \\
\hline $\mathrm{X} 4$ & 0.803 \\
\hline $\mathrm{X} 5$ & 0.870 \\
\hline $\mathrm{X} 7$ & 0.767 \\
\hline $\mathrm{X} 8$ & 0.766 \\
\hline $\mathrm{X} 9$ & 0.776 \\
\hline
\end{tabular}

\begin{tabular}{|l|l|}
\hline $\mathrm{X} 10$ & 0.845 \\
\hline $\mathrm{X} 11$ & 0.826 \\
\hline $\mathrm{X} 12$ & 0.800 \\
\hline $\mathrm{X} 13$ & 0.787 \\
\hline $\mathrm{X} 14$ & 0.782 \\
\hline $\mathrm{X} 15$ & 0.820 \\
\hline
\end{tabular}

Sumber: hasil olah data dengan SPSS 23

Hasil Uji Persyaratan MSA diatas, semua variable mempunyai nilai MSA > 0,5 sehingga semua variabel dinyatakan valid dan dapat digunakan untuk analisis selanjutnya.

\section{Komunalitas}

Hasil dari uji komunalitas adalah sebagai berikut:

Tabel 5

\section{Communalities}

\begin{tabular}{|l|r|r|}
\hline & \multicolumn{1}{|c|}{ Initial } & \multicolumn{1}{|c|}{ Extraction } \\
\hline $\mathrm{X} 1$ & 1.000 & .815 \\
$\mathrm{X} 2$ & 1.000 & .760 \\
$\mathrm{X} 3$ & 1.000 & .633 \\
$\mathrm{X} 4$ & 1.000 & .599 \\
$\mathrm{X} 5$ & 1.000 & .576 \\
$\mathrm{X} 7$ & 1.000 & .756 \\
$\mathrm{X} 8$ & 1.000 & .736 \\
$\mathrm{X} 9$ & 1.000 & .688
\end{tabular}




\begin{tabular}{|l|l|l}
$\mathrm{X} 10$ & 1.000 \\
$\mathrm{X} 11$ & 1.000 & .549 \\
$\mathrm{X} 12$ & 1.000 & .696 \\
$\mathrm{X} 13$ & 1.000 & .749 \\
$\mathrm{X} 14$ & .815 \\
$\mathrm{X} 15$ & 1.000 & .788 \\
& 1.000 & .693 \\
\hline
\end{tabular}

Extraction Method: Principal Component Analysis.

Sumber : Hasil olah data dengan SPSS 23

Tabel di atas menunjukkan bahwa nilai komunalitas semua variabel $>0,5$, maka asumsi komunalitas terpenuhi.

Tabel di atas menunjukkan seberapa besar sebuah variabel dapat menjelaskan faktor. Misal X1 nilainya

\section{Tabel 6}

Total Variance Explained

\begin{tabular}{|c|c|c|c|c|c|c|c|c|c|}
\hline \multirow[b]{2}{*}{$\begin{array}{l}\text { Compon } \\
\text { ent }\end{array}$} & \multicolumn{3}{|c|}{ Initial Eigenvalues } & \multicolumn{3}{|c|}{$\begin{array}{c}\text { Extraction Sums of Squared } \\
\text { Loadings }\end{array}$} & \multicolumn{3}{|c|}{$\begin{array}{c}\text { Rotation Sums of Squared } \\
\text { Loadings }\end{array}$} \\
\hline & Total & $\begin{array}{c}\% \text { of } \\
\text { Variance }\end{array}$ & $\begin{array}{l}\text { Cumulati } \\
\text { ve } \%\end{array}$ & Total & $\begin{array}{c}\% \text { of } \\
\text { Variance }\end{array}$ & $\begin{array}{l}\text { Cumulati } \\
\text { ve } \%\end{array}$ & Total & $\begin{array}{c}\% \text { of } \\
\text { Variance }\end{array}$ & $\begin{array}{l}\text { Cumulati } \\
\text { ve } \%\end{array}$ \\
\hline 1 & 4.579 & 32.709 & 32.709 & 4.579 & 32.709 & 32.709 & 2.519 & 17.996 & 17.996 \\
\hline 2 & 1.843 & 13.161 & 45.870 & 1.843 & 13.161 & 45.870 & 2.206 & 15.760 & 33.756 \\
\hline 3 & 1.252 & 8.944 & 54.815 & 1.252 & 8.944 & 54.815 & 2.194 & 15.668 & 49.424 \\
\hline 4 & 1.142 & 8.156 & 62.970 & 1.142 & 8.156 & 62.970 & 1.582 & 11.302 & 60.726 \\
\hline 5 & 1.038 & 7.416 & 70.387 & 1.038 & 7.416 & 70.387 & 1.352 & 9.660 & 70.387 \\
\hline 6 & .727 & 5.196 & 75.583 & & & & & & \\
\hline 7 & .678 & 4.845 & 80.428 & & & & & & \\
\hline 8 & .620 & 4.427 & 84.855 & & & & & & \\
\hline 9 & .513 & 3.667 & 88.522 & & & & & & \\
\hline 10 & .406 & 2.898 & 91.420 & & & & & & \\
\hline 11 & .378 & 2.697 & 94.116 & & & & & & \\
\hline 12 & .334 & 2.386 & 96.503 & & & & & & \\
\hline 13 & .264 & 1.886 & 98.389 & & & & & & \\
\hline 14 & .226 & 1.611 & 100.000 & & & & & & \\
\hline
\end{tabular}

Extraction Method: Principal Component Analysis.

Sumber :Hasil olah data dengan SPSS 23

Berdasarkan tabel di atas, lihat kolom "Component" yang menunjukkan bahwa ada 5 komponen yang dapat mewakili variabel. Perhatikan kolom "Initial Eigenvalues" yang dengan SPSS kita tentukan nilainya 1 (satu). Varians bisa diterangkan oleh faktor 1 adalah $4,579 / 5 \times 100 \%=32,709 \%$. Oleh faktor 2
0,815, artinya variabel X1 dapat menjelaskan faktor sebesar $81,5 \%$. Begitu pula dengan variabel lainnya, di mana semuanya $>50 \%$, oleh karenanya dapat disimpulkan bahwasanya semua variabel dapat menjelaskan faktor.

\section{Faktor Yang Sekiranya Dapat Terbentuk}

Tabel Total Variance Explained di bawah ini berguna untuk menentukan berapakah faktor yang mungkin dapat dibentuk. 
dan 5. Sehingga semua komponen yang terbentuk ada 5 faktor baru yang dapat mewakili semua variable yang dianalisis.
Nilai Eigenvalues diatas apabila digambarkan dalam bentuk grafik adalah sebagai berikut:

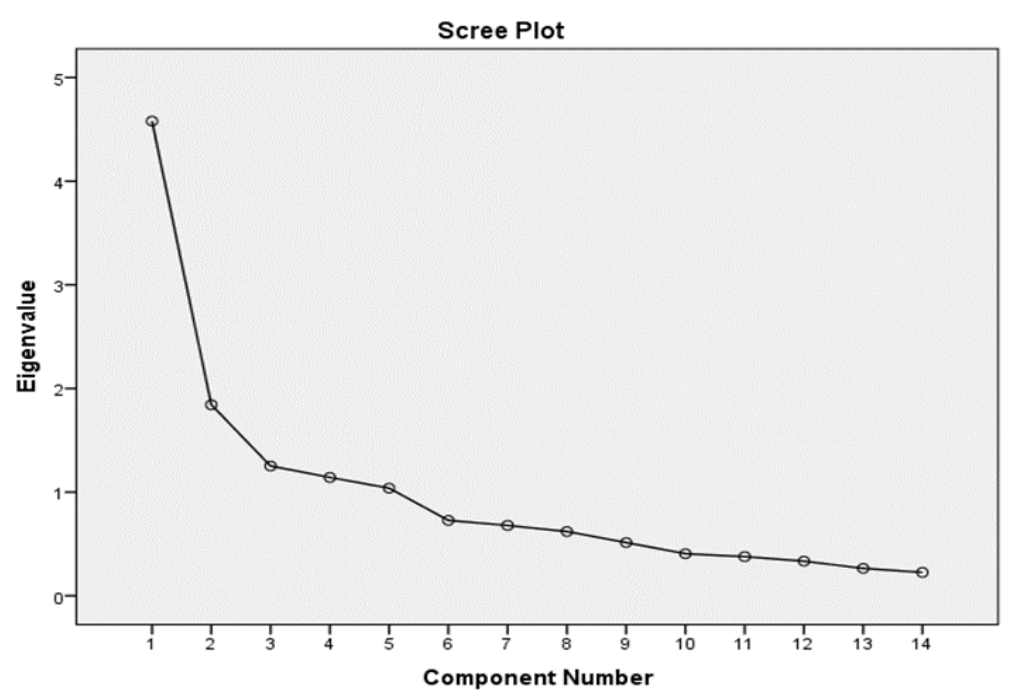

Sumber :Hasil olah data dengan SPSS 23

Gambar 1

Grafik Nilai Eigenvalues

Berdasarkan Scree Plot diatas, tampak bahwa komponen yang nilai eigenvalues diatas 1 ada 5 faktor, maka factor yang terbentuk adalah 5 faktor baru sesuai dengan yang dijelaskan pada table Total Variance Explained diatas sebelumnya.

\section{Factor Loading}

Setelah kita mengetahui bahwa faktor maksimal yang bisa terbentuk adalah 5 faktor, selanjutnya kita melakukan penentuan masing-masing variabel akan masuk ke dalam faktor mana, apakah faktor 1, 2, 3, 4, ataukah 5 . Cara menentukan tersebut adalah dengan melihat tabel Component Matrix seperti di bawah ini:

Tabel 7

Component Matrix ${ }^{a}$

\begin{tabular}{|l|r|r|r|r|r|}
\hline & \multicolumn{7}{|c|}{ Component } \\
\cline { 2 - 6 } & 1 & 2 & 3 & 4 & \multicolumn{1}{|c|}{5} \\
\hline X12 & .677 & -.511 & .043 & -.027 & -.166 \\
X15 & .658 & .252 & -.103 & -.340 & -.265 \\
X13 & .647 & -.606 & -.014 & .068 & -.158 \\
X11 & .629 & .543 & .007 & .049 & .066 \\
X14 & .610 & -.527 & -.259 & .106 & -.244 \\
X3 & .604 & .011 & -.249 & -.452 & .043 \\
X10 & .602 & .024 & -.070 & .424 & -.035 \\
X9 & .601 & .450 & .035 & .345 & .063
\end{tabular}




\begin{tabular}{|l|r|r|r|r|r|}
$\mathrm{X} 4$ & .559 & .317 & -.247 & -.351 & .043 \\
$\mathrm{X} 5$ & .499 & .002 & -.258 & -.136 & .491 \\
$\mathrm{X} 8$ & .474 & .424 & .079 & .412 & -.395 \\
$\mathrm{X} 1$ & .440 & -.219 & .734 & -.057 & .177 \\
$\mathrm{X} 2$ & .416 & .649 & -.277 & .035 \\
$\mathrm{X} 7$ & .497 & -.185 & -.100 & .336 & .643 \\
\hline
\end{tabular}

Extraction Method: Principal Component Analysis.

a. 5 components extracted.

Sumber :Hasil olah data dengan SPSS 23

Tabel di atas menunjukkan seberapa besar sebuah variabel berkorelasi dengan faktor yang akan dibentuk. Misal: X12 berkorelasi sebesar 0,677 dengan faktor 1, kemudian berkorelasi $-0,511$ dengan faktor 2, sebesar 0,043 dengan faktor 3, sebesar $-0,027$ dengan faktor 4 dan sebesar -0,166 dengan faktor 5. Oleh karena X.12 paling berkorelasi dengan faktor 1, maka X.12 dapat disebut sebagai anggota kelompok atau faktor 1. Namun agar penentuan kelompok tersebut lebih baik, maka perlu dilakukan rotasi faktor. Dalam hal ini rotasi dilakukan dengan metode varimax kaizer normalization. Hasilnya seperti di bawah ini.

\section{ROTASI FAKTOR}

Hasil rotasi factor ditampilkan dalam tabel di bawah ini:

Tabel 8

Rotated Component Matrix ${ }^{\mathrm{a}}$

\begin{tabular}{|l|r|r|r|r|r|}
\hline & \multicolumn{5}{|c|}{ Component } \\
\cline { 2 - 6 } & 1 & 2 & 3 & 4 & \multicolumn{1}{c|}{5} \\
\hline X13 & .865 & .101 & .056 & .184 & .140 \\
X14 & .855 & .167 & .114 & -.076 & .101 \\
X12 & .793 & .194 & .072 & .261 & .094 \\
X4 & .041 & .733 & .214 & .027 & .114 \\
X3 & .280 & .727 & .002 & .079 & .141 \\
X15 & .230 & .706 & .315 & .142 & -.150 \\
X8 & .118 & .077 & .826 & .045 & -.181 \\
X9 & .006 & .216 & .749 & .131 & .252 \\
X11 & -.083 & .477 & .630 & .179 & .180 \\
X10 & .382 & .058 & .576 & .024 & .260 \\
X1 & .230 & -.054 & .056 & .856 & .152 \\
X2 & .044 & .270 & .169 & .810 & -.041 \\
X7 & .205 & -.029 & .153 & .080 & .827 \\
X5 & .117 & .453 & .030 & .034 & .595 \\
\hline
\end{tabular}

Extraction Method: Principal Component Analysis.

Rotation Method: Varimax with Kaiser Normalization.

a. Rotation converged in 6 iterations.

Sumber :Hasil olah data dengan SPSS 23 
Penentuan variabel masuk faktor mana ditentukan dengan melihat nilai korelasi terbesar. Pada tabel di atas telah diurutkan dari nilai yang terbesar ke yang terkecil per faktor.

Perhatikan baik-baik di atas:X.13 korelasi terbesar dengan faktor 1 yaitu
0,865 , begitu pula X14: 0,855 dan X.12= 0,793 .

Yang paling berkorelasi dengan faktor 2 adalah X4, X3 dan X.15. Begitu seterusnya sampai faktor 5 .

Maka dapat disimpulkan anggota masing-masing faktor:

\section{Tabel 9}

Ringkasan masing masing faktor

\begin{tabular}{|c|c|c|c|}
\hline Faktor & Eigenvalue & Anggota & Faktor Loading \\
\hline 1 & 4.579233493 & $\mathrm{X} 13$ & .865 \\
\hline & & $\mathrm{X} 14$ & .855 \\
\hline & & $\mathrm{X} 12$ & .793 \\
\hline 2 & 1.842592233 & $\mathrm{X} 4$ & .733 \\
\hline & & $\mathrm{X} 3$ & .727 \\
\hline 3 & & $\mathrm{X} 15$ & .706 \\
\hline & 1.252223142 & $\mathrm{X} 8$ & .826 \\
\hline & & $\mathrm{X} 9$ & .749 \\
\hline & & $\mathrm{X} 11$ & .630 \\
\hline 4 & & $\mathrm{X} 10$ & .576 \\
\hline & 1.141815292 & $\mathrm{X} 1$ & .856 \\
\hline 5 & & $\mathrm{X} 2$ & .810 \\
\hline & 1.038271096 & $\mathrm{X} 7$ & .527 \\
\hline
\end{tabular}

Sumber data : Olahan Peneliti

Berdasarkan hasil dari nilai Total Variance Explained, dimana nilai eigenvalue terbesar adalah Faktor 1 yang anggotanya terdiri dari X13, X14 dan X12. Maka dapat dinyatakan bahwa Faktor yang paling dominan adalah faktor 1 dimana anggota kelompoknya terdiri dari X13, X14 dan X12.

\section{Interpretasi Hasil Penelitian}

Berdasarkan olah data Rotated Component Matrix dapat dideskripsikan hasil rotasi faktor varimax pada tabel di atas adalah variabel 13, 14, 12 mengelompok pada faktor pertama (1). Variabel 13 berkaitan dengan saran dalam memilih program studi yaitu dari guru, variabel 14 saran dari teman, dan variabel 12 yaitu saran dari orangtua. Ketiga variabel ini menunjukkan nilai factor loading diatas 0,5, dan mengelompok pada faktor yang sama. Ketiga faktor ini berkaitan dengan faktor eksternal yang memengaruhi siswa dalam memilih program studi, ini dapat dikatakan sebagai faktor saran.

Hasil analisis faktor untuk faktor kelompok reference mempunyai nilai untuk variabel saran dari guru 13 dengan nilai factor loading sebesar 0,865 ; variabel saran dari teman 14 dengan nilai factor loading 0,855 dan untuk variabel saran dari orang tua 12 dengan nilai factor loading sebesar 0,793.

Selanjutnya terdapat tiga $(4,3,15)$ variabel yang mengelompok pada faktor kedua yaitu variabel 4 berkaitan dengan kegiatan ilmiah seperti seminar, workshop, 
dan lain-lain, variabel 3 berkaitan dengan reputasi alumni, dan variabel 15 berkaitan dengan hubungan antara sesama teman dan antara mahasiswa dengan dosen yang cukup baik. Ketiga variabel ini menunjukan nilai factor loading diatas 0,5 dan berada dalam satu kelompok pada faktor yang sama yaitu reputasi program studi. Hasil analisis faktor untuk reputasi program studi yaitu variabel Prodi ilmu komunikasi sering mengadakan forum forum ilmiah seperti seminar workshop dll (4) dengan nilai factor loading sebesar 0,733; variabel Reputasi dari alumni/lulusan prodi Ilmu Komunikasi (3) dengan nilai factor loading sebesar 0,727 dan untuk variabel hubungan antara sesama teman dan antara mahasiswa dengan dosen cukup baik (15) dengan nilai factor loading sebesar 0,706.

Berikutnya terdapat empat variabel yaitu varibel $8,9,11,10$ yang mengelompok pada faktor ketiga. Variabel 8 berkaitan dengan fasilitas beasiswa seperti beasiswa olah raga dan prestasi akademik. Variabel 9 berkaitan dengan banyaknya perusahaan yang membutuhkan sarjana di bidang komunikasi. Variabel 11 berkaitan dengan fasilitas penunjang seperti laboratorium media, laboratorium komputer, jaringan internet. Variabel 10 berkaitan dengan karir lulusan prodi komunikasi. Keempat variabel ini menunjukkan nilai faktor loading diatas 0,5 dan berada dalam kelompok faktor yang sama. Keempat varibel ini berkaitan dengan fasilitas, karir dan beasiswa.

Hasil analisis faktor untuk fasilitas, karir dan beasiswa untuk variabel Adanya beasiswa bagi mahasiswa yang berprestasi (8) dengan nilai factor loading sebesar 0,826; variabel Lulusan prodi Ilmu komunikasi banyak dibutuhkan (9) dengan nilai factor loading sebesar 0,749 ; variabel Fasilitas penunjang seperti laboratorium media, lab komputer, internet, dll. (11) dengan nilai factor loading sebesar 0,630 dan untuk variabel Karir dan masa depan prodi ilmu komunikasi lebih menjanjikan dibanding prodi lain (10) dengan nilai factor loading sebesar 0,579.

Selanjutnya ada dua variabel (1 dan 2) yaitu status akreditasi program studi dan reputasi dosen yang mengelompok pada faktor keempat. Kedua variabel ini memiliki nilai faktor diatas 0,5 dan berada pada kelompok yang sama kedua varibel ini berkaitan dengan status akreditasi program studi ilmu komunikasi dan reputasi dosen di prodi ilmu komunikasi, maka dapat dikatakan sebagai faktor status prodi ilmu komunikasi.

Hasil analisis faktor untuk status prodi ilmu komunikasi untuk variabel Status akreditasi program studi (1) dengan nilai factor loading sebesar 0,859 dan untuk variabel Reputasi dosen/tenaga pengajar (2) dengan nilai factor loading sebesar 0,810 .

Dua variabel terakhir yaitu variabel 7 dan varibel 5 mengelompok pada faktor kelima. Kedua varibel ini berkaitan dengan kegiatan dalam perkuliahan yaitu kunjungan keberbagai instansi dan biaya kuliah yang terjangkau. Kedua faktor ini menunjukkan faktor loading lebih dari 0,5 dan mengelompok pada faktor yang sama, yang disebut sebagai faktor biaya.

Hasil analisis faktor untuk faktor biaya dengan variabel biaya kuliah terjangkau (7) dengan nilai factor loading sebesar 0,827 dan untuk variabel Prodi Ilmu komunikasi rutin mengadakan kunjungan ke media, instansi sesuai 
kosentrasi masing2 (5) dengan nilai factor loading sebesar 0,595.

Faktor-faktor

tersebut

menunjukkan beberapa faktor yang menjadi pertimbangan mahasiswa di dalam memilih program studi ilmu komunikasi di Universitas Budi Luhur sebagai tempat untuk melanjutkan studi. Skor tertinggi pada faktor pertama yaitu berkaitan dengan saran dalam memilih program studi yaitu dari guru, teman dan orang tua.

Skor tertinggi pada faktor kedua adalah berkaitan dengan kegiatan ilmiah seperti seminar, workshop, dan lain-lain, lalu terkait dengan reputasi alumni, dan juga berkaitan dengan hubungan antara sesama teman dan antara mahasiswa dengan dosen yang cukup baik.

Menurut Direktur Promosi

Universitas Budi Luhur bapak Joko

Sutrisno, M.Kom menanggapi hasil data kuantitatif tersebut berdasarkan hasil wawancara Peneliti sehubungan dengan strategi komunikasi pemasaran yang dilakukan ada beberapa hal. Tim promosi saat ini sudah melakukan promosi-promosi langsung ke sekolah-sekolah SMK-SMA di sekitar Jakarta Selatan dan Tangerang, namun terkait dengan orang tua, saat ini belum ada, namun tim promosi sudah melakukan pendekatan melalui media yang dikonsumsi oleh orang tua, yaitu memasang iklan melalui TV di channel Metro TV dan melakukan kegiatan talkshow di radio Elshinta melakukan promosi dengan membawa nama universitas untuk menjaring antusiasme orang tua.

Terkait dengan kegiatan ilmiah seperti seminar, workshop dan promosi fikom sudah melakukan hal tersebut dan juga sudah mempublish beritanya melalui media sosial \& website lebih lanjut lagi menurut Bapak Joko lebih baik promosi melalui website, dan promosi yang dilakukan dalam bentuk teks saja, gambar hanya untuk penambahan baru bisa diunduh. Karena tidak semua bisa melihat gambar secara langsung. Acuannya yang dimiliki oleh Fakultas Ilmu Komunikasi Universitas Budi Luhur. Jadi program studi peminatannya dijabarkan dibuat seinformatif mungkin. Jangan terlalu prolog yang terlalu banyak. Misalkan peminatan cyber, langsung ke alasan kenapa dibutuhkan dan prospek pekerjaannya. Biar langsung stright to the point. Diharapkan semua Kepala Program Studi segera mengirimkan apa saja yang bisa dipromosikan oleh Kepala Program Studi mereka. Jadi tim website bisa langsung melakukan proses promosi tersebut. Contohnya langsung ke manfaat dan konsentrasi apa saja yang dibuka serta prospek kerja sehingga peminat langsung tahu ingin memilih konsentrasi. Ini sudah dilakukan sebelum keluar hasil penelitian. Jadi sekarang sedang diseragamkan dari universitas ke tiap fakultas. Setelah ada teks, dibuat juga gambar atau e-flyer yang bisa diunduh oleh pengguna website universitas.

Tidak semua orang mudah mengunduh gambar oleh sebab itu perlu ada intro penggunaan teks terlebih dahulu. Memang sudah menjadi concern tim untuk memperbaiki website. Ternyata memang hal itu yang perlu dilakukan. Sudah pernah diarahkan tapi belum jalan tahun lalu. Sekarang sudah rektor yang mengarahkan. Tim ada Al, Dara, Adit, Dzikri, dan Fachry dari Radio Budi Luhur. Banyak tim promosi dari Radio Budi Luhur. Anakanak mengerti mau tim promosi, mereka paham apa yang diinginkan. Apa yang tim promosi mau tinggal disampaikan kepada 
mereka. Secara tidak langsung tim promosi mempelajari gaya anak-anak jaman sekarang sehingga dapat masuk ke dalam dunia mereka dan dapat melakukan promosi yang tepat.

Menurut bapak Joko diperlukan hal yang lebih detail. Jangan hanya mengandalkan promosi sendiri di Penerimaan Mahasiswa Baru (PMB) namun juga banyak faktor yang harusnya dilihat. Apakah dengan tampilan webiste saja sudah cukup. Jangan sampai hanya menjual ilusi, apa yang dipromosikan berbeda dengan kenyataan di dalamnya. Karena peminat atau calon mahasiswa pun berhak mendapatkan apa saja yang telah dipromosikan. Paling tidak jangan terlalu jauh dari yang telah dipromosikan. Penelitian lebih lanjut bisa dilanjutkan mengenai faktor lain supaya kita bisa rekomendasikan ke pihak lain, bukan hanya tim Penerimaan Mahasiswa Baru (PMB). Bisa diteliti sebelum mereka masuk, sedang berkuliah, atau bahkan sampai pada saat mereka sedang menyusun Tugas Akhir.

Menangkap yang baru masuk, mereka sudah didapat. Tapi bagaimana mereka pada saat proses perkuliahan. Apakah faktor seperti "oh, dosen sulit ditemui dan hal lain" menjadi kepercayaan peminat tidak berlangsung lama. Apakah itu menjadi alasan dominan atau pihak lain. Ranahnya orang-orang Fakultas Teknologi Informasi tidak bisa meneliti hal sosial. Bisa mungkin dari orang manajemen atau komunikasi. Mereka hanya sebatas penggunaan sistem dan teknologi. Perlu diteliti lagi mereka yang di semester 4 dan 5. Apa yang mereka rasakan, apa keluhan mereka dan yang sedang melakukan Tugas Akhir supaya tim promosi bisa melakukan penelitian lebih lanjut untuk tim dari Promosi atau siapapun itu demi kebutuhan universitas.

Mereka yang sedang berkuliah dan sedang tugas akhir tim promosi dan seluruh bagian universitas harus tahu apa yang mahasiswa rasakan supaya kepercayaan mereka terhadap universitas masih ada. Apakah mereka masih mau merekomendasikan kampus ini kepada saudara, adik, atau kakak mereka untuk melanjutkan kuliah di Budi Luhur. Apa alasan yang membuat mahasiswa tersebut tidak mau merekomendasikan kampus ini lagi pun menjadi hal yang sangat penting untuk diteliti di penelitian selanjutnya. Bukan hanya dari tim promosi tapi dari segi akademis juga harus tahu. Sama seperti halnya ada beberapa fakultas yang mendapat keluhan mengenai dosen pada saat sidang Tugas Akhir ada yang ditakuti. Entah mungkin karena dianggap killer. Tim promosi belum tahu yang lain sudah puas atau belum. Hal tersebut diperlukan untuk membuat strategi komunikasi pemasaran yang lebih baik lagi.

\section{SIMPULAN}

Berdasarkan analisis faktor melalui uji statistic menunjukkan beberapa faktor yang menjadi pertimbangan mahasiswa di dalam memilih program studi ilmu komunikasi di Universitas Budi Luhur yaitu kelompok reference, fasilitas, karir dan beasiswa, status program studi, dan biaya.

Berdasarkan hasil rotasi faktor berdasarkan tingkat kepentingan faktor maka ditemukan bahwa faktor kelompok reference merupakan varibel utama yang menjadi dasar mahasiswa memilih program studi ilmu komunikasi, disusul faktor fleksibilitas, staus program studi dan terakhir faktor biaya. 
Perlu diteliti lagi mereka yang di semester 4 dan 5. Apa yang mereka rasakan, apa keluhan mereka dan yang sedang melakukan Tugas Akhir supaya tim promosi bisa melakukan penelitian lebih lanjut untuk tim dari Promosi atau siapapun itu demi kebutuhan universitas. Jangan hanya berfokus pada promosi tetapi bagaimana faktor lain yang dihadapi mahasiswa yang sedang berkuliah menjadi pengaruh untuk akan merekomendasikan kampus Universitas Budi Luhur khususnya Fakultas Ilmu Komunikasi Budi Luhur atau tidak kepada orang lain setelah mereka lulus. Karena kepercayaan bisa menurun seiring berjalannya waktu, tinggal bagaimana pihak fakultas bisa mempertahankan kepercayaan itu atau tidak.

Berdasarkan kesimpulan penelitian maka peneliti menyarankan kepada program studi ilmu komunikasi dan direktorat promosi Universitas Budi Luhur untuk memeperhatikan langkahlangkah berikut : promosi hendaknya menggunakan kelompok reference seperti, alumni, mahasiswa, orangtua, guru SMA; meningkatkan reputasi prodi dan universitas melalui kualitas dosen, mahasiswa, dan alumni; meningkatkan fasilitas dalam menunjang proses belajar mengajar dengan terus berinovasi dalam sistem pembelajaran; dan prodi ilmu komunikasi hendaknya terus mengembangkan kerjasama dengan berbagai pihak.

\section{UCAPAN TERIMA KASIH}

Puja dan puji syukur kehadirat ALLAH S.W.T karena telah memberikan kesempatan dan kemudahan dalam melakukan proses penelitian. Untuk itu kami menyampaikan ucapan terima kasih yang sebesar-besarnya kepada Bapak Kasih Hanggoro, MBA selaku Ketua Yayasan Pendidikan Budi Luhur Cakti beserta Ibu yang telah memfasilitasi kegiatan ini; Bapak Dr. Ir. Krisna Adiyarta M., M.Sc selaku Direktur Riset dan PPM serta tim dari DRPM di lingkungan Universitas Budi Luhur yang telah mendukung; Ibu Dr. Umaimah Wahid dan Ibu Denik Iswardani Witarti, Ph.D selaku Reviewer Penilai Penelitian; dan semua pihak yang telah mendukung penelitian ini.

\section{DAFTAR PUSTAKA}

Engel, James F., Roger D Blackwell, dan Paul W Miniard. (1994). Perilaku Konsumen, Alih bahasa Budiyanto, Jakarta : Binarupa Aksara.

Kotler, Philip. (1997). Manajemen Pemasaran. Alih Bahasa : benyamin Molan. Jakarta : PT. INDEKS.

Kotler, Philip. (2003). Marketing Insight from $A$ to $Z$ (alih bahasa, Anies Lastiati). Jakarta: Erlangga.

Kotler, Philip. (2009). Manajemen Pemasaran, Edisi 13. Jakarta : Erlangga

Kotler, Philip and Kevin Lane Keller. (2012). Marketing Management, Edition 14, England: Pearson Education

Kotler, Philip and Kevin Lane Keller. (2012). Marketing Management. Edition 14. England : Pearson Education

Mangkunegara, A. A. Anwar Prabu. (2002). Perilaku Konsumen. Bandung : PT. Refika Aditama.

Muzammil, Moh. \& Harsasi, Meirani. (2011). faktor-faktor yang mempengaruhi mahasiswa memilih program studi Akuntansi Universitas 
Terbuka. Jakarta: Universitas Terbuka.

Rachmat Kriyantono. (2010). Teknis Praktis Riset Komunikasi: Disertai Contoh Praktis Riset Media, Public Relations, Advertising, Komunikasi Organisasi, KomunikasiPemasaran, Cetakan ke-5. Jakarta: Kencana Prenada Media Group.

Rachmat Kriyantono. (2007). Teknik Praktis Riset Komunikasi. Jakarta: Kencana Prenada Media Group.

Schiffman, Leon, L. Lazar Kanuk. (2008). Perilaku Konsumen. Alih Bahasa : Zoelkifli Kasip. Jakarta : PT. INDEKS.

Setiadi, Nugroho. (2008). Perilaku Konsumen Konsep dan Implikasi untuk Strategi dan Penelitian Pemasaran. Jakarta : Kencana Prenada Group.

Simamora, Bilson. (2001). Panduan Riset perilaku Konsumen. Jakarta : PT. Gramedia Pustaka Utama

Stanton, William J. (1996). Prinsip Pemasaran Jilid II. Alih Bahasa Sadu Sundaru. Jakarta : Erlangga Swastha DH, Basu dan Handoko. (2000). Manajemen Pemasaran, Analisa Perilaku Konsumen. Yokyakarta : BPFE.

Sunarto. (2004). Prinsip - prinsip Pemasaran edisi ke 2. Yogyakarta: AMUS, UST Press dan Mahenoko Total Design Yogyakarta.

Suryani, Tatik. (2013). Perilaku Konsumen di Era Internet : Implikasi Pada Strategi Pemasaran. Yogyakarta : Graha Ilmu

Sutisna. (2002). Perilaku Konsumen dan Komunikasi Pemasaran. Bandung : PT. Remaja Rodaskaya.
Sumarwan, Ujang. (2002). Perilaku Konsumen Teori dan Penerapannya dalam Pemasaran. Bogor: Ghalia Indonesia. 